\title{
ALDREN: A Methodological Framework to Support Decision-Making and Investments in Deep Energy Renovation of Non-Residential Buildings
}

\author{
Marta Maria Sesana ${ }^{1, *(1)}$, Graziano Salvalai ${ }^{2}\left(\mathbb{D}\right.$, Diletta Brutti $^{2}\left(\mathbb{D}\right.$, Corinne Mandin $^{3}\left(\mathbb{D}\right.$ and Wenjuan Wei ${ }^{3}$ \\ 1 Polo Territoriale di Lecco, Politecnico di Milano, 23900 Lecco, Italy \\ 2 Department of Architecture Built Environment and Construction Engineering, Politecnico di Milano, \\ 20133 Milan, Italy; graziano.salvalai@polimi.it (G.S.); diletta.brutti@polimi.it (D.B.) \\ 3 Centre Scientifique et Technique du Bâtiment, 84 Avenue Jean Jaurès, 77447 Marne-La-Vallée, France; \\ corinne.mandin@cstb.fr (C.M.); wenjuan.wei@cstb.fr (W.W.) \\ * Correspondence: marta.sesana@polimi.it
}

check for updates

Citation: Sesana, M.M.; Salvalai, G.; Brutti, D.; Mandin, C.; Wei, W. ALDREN: A Methodological Framework to Support DecisionMaking and Investments in Deep Energy Renovation of Non-Residential Buildings. Buildings 2021, 11,3. http:/ / dx.doi.org/10.3390/buildings11010003

Received: 3 November 2020 Accepted: 19 December 2020

Published: 23 December 2020

Publisher's Note: MDPI stays neutral with regard to jurisdictional claims in published maps and institutional affiliations.

Copyright: (c) 2020 by the authors. Licensee MDPI, Basel, Switzerland. This article is an open access article distributed under the terms and conditions of the Creative Commons Attribution (CC BY) license (https: / / creativecommons.org/ licenses/by/4.0/).
Abstract: Since 2002, the Energy Performance of Buildings Directive (EPBD) has set up the path to improve the efficiency gains in the EU building sector, including measures that should accelerate the rate of building renovation towards more energy efficient systems. Under the $2010 \mathrm{EPBD}$, all EU countries have established independent energy performance certification systems supported by independent mechanisms of control and verification. The EU directive 2018/844 has introduced different novelties and one of these regards the possibility for the Member States, together with the Long-Term Renovation Strategies (LTRS), to introduce an optional Building Renovation Passport Article 2a.1(c), considered as an empowering document that gives more reliable and independent information on the potential for energy savings that is tied up in their buildings. On 14 October 2020, the European Commission launched its Communication and Strategy on the Renovation Wave initiative, intending to double the current Europe's renovation rate to make the continent carbon neutral by 2050. However, current practices and tools of energy performance assessment and certification applied across Europe face several challenges. In this context, the ALDREN project is a methodological framework that aims to support decision-making and investment in deep energy renovation of nonresidential buildings, based on a set of procedures (modules) that consist in the step-by-step implementation of protocols to assess the energy performance, indoor environmental quality, and financial value of buildings, before and after the energy renovation. The paper presents the ALDREN overall procedure with a focus on the development of the Building Renovation Passport and its application to an Italian office building.

Keywords: Building Renovation Passport; building logbook; renovation roadmap; energy renovation; modular structure; non-residential buildings

\section{Introduction}

Over 3 years ago, a consortium of partners across seven EU countries came together to complete a proposal to the Horizon 2020 research programme, Energy Efficiency call EE11-2017. The objective of this research was overcoming the regulatory and nonregulatory barriers to facilitate the renovation of existing building stocks. In this context, the ALliance for Deep RENovation in buildings (ALDREN) project started in November 2017. The project was led by the French scientific and technical center for building (CSTB) with a consortium of 8 partners: Politecnico di Milano, Danish Technical University, CERTIVEA, REHVA, Instituto Valenciano de la Edification, ENBEE, and VERCO [1].

The ALDREN project aims at implementing the European Common Voluntary Certification Scheme as backbone along the whole deep renovation process. The ALDREN procedure allows achieving higher renovation rates and better renovation quality by overcoming market barriers and preparing the ground for investments. 
ALDREN with its objectives and outcomes has high potential to boost the renovation of the existing building stock, supporting the EU in tackling the energy use and emissions of the construction sector, and to meet both the EU's 2030 emission reduction target and the climate neutrality challenge by 2050 .

Buildings account for $40 \%$ of total energy consumption and around $75 \%$ of them are energy inefficient. Energy efficiency in buildings suffers from underinvestment and numerous barriers. While buildings are regularly maintained or improved, energy saving investments are often disregarded because they face a competition for scarce capital, a lack of trustworthy information, lack of skilled workers, or doubts on the possible benefits. Nowadays, $1.2 \%$ of buildings are renovated for energy improvements every year. At this rate, it would take a century to upgrade the building stock to near-zero energy levels [2].

While Europe's buildings are unique and diverse and reflect the culture of the continent, many of them are also old, and inefficient. More than 220 million buildings, representing approximately $85 \%$ of the building stock, were built before 2001 and will mostly still be standing in 2050. They are also unprepared for the ongoing and future climate changes, such as increasing temperatures and extreme weather events [3].

Building renovation is a clear priority of the Commission and the Renovation Wave is a flagship initiative under the EU Green Deal. This transformation will be possible with effective policies and support instruments. The Renovation Wave is opening the way to measures that will transform the building sector, but the implementation of policies and support instruments must become faster and more ambitious [4].

A key point of future policies is that buildings are increasingly expected to meet higher performance requirements, reaching a positive balance between the produced and required energy. Currently, the scientific community is stressing the need and advantages of a new dimension of interconnected buildings, going from the building level to the district one. Smart technologies and electrical mobility play a central role in this vision, where aspects such safety, resilience, and user awareness become more and more crucial. Another important aspect is the inclusion of climate change impact on buildings. New extreme, short periods of intense cold or heat are likely to have an influence on both heating and cooling loads as well as best efficiency measures chosen to reach the Net Zero Energy Building (NZEB) target [5].

The EU Commission moreover highlighted that renovation can be held back by barriers at different points in the renovation value chain-from the initial decision to engage in renovation, to financing and completion of the project. For instance, when considering a renovation, benefits from energy savings might be uncertain or poorly explained and understood, especially by the end-users. They can be difficult to measure and monetize [3]. Multicriteria decision-making (MCDM) methodologies may help to quantify qualitative parameters, creating priorities among different alternatives, such as in outranking procedures or value-measurement models.

A literature review on building energy renovation [6-9], moreover reveals that cultural/social indicators have seldom been used, while health/human criteria have been employed more frequently, in relation to internal comfort or indoor health conditions. Environmental criteria are always taken into account, measuring reductions in energy consumption or $\mathrm{CO}_{2}$ emissions. However, the most common indicators supporting the decision-making processes in building stock energy retrofits are the economic ones because they provide measurable and straightforward parameters to quantify the cost effectiveness of each design option, and they allow for the evaluation of economic feasibility of the interventions.

In this context, the EU Renovation Wave aims to double the EU annual energy renovation rate by 2030 to cut emissions, boost economic recovery, and reduce energy poverty. It is a much needed and ambitious initiative, the Renovation Wave, including Building Renovation Passports and Digital Building Logbooks, and a "deep renovation" standard as part of the revision of the Energy Performance of Buildings Directive (EPBD). The ALDREN 
procedure and outcomes, which are presented in this paper, can properly contribute to reach the objectives in line with the Green Deal Initiatives.

The ALDREN solutions are dedicated to: (1) associate low energy renovation with high quality indoor environments to trigger renovation and to promote health and comfort; (2) align market recognition of high quality with enhanced building value by financial tools and building capacity; (3) harmonize the Energy performance rating based on the European Voluntary Certification Scheme (EVCS) verified by measurements to increase comparability, confidence, and market uptake by standardized renovation solutions (CEN/ISO). These solutions have been integrated in a consistent, common way in a Building Renovation Passport to ensure the results and effective financing of a step-by-step renovation. To deal with the overall solutions outlined above, the ALDREN project investigates multiple topics thanks to the various partners' expertise and crucial interaction between them, for the definition of respective, but correlated protocols.

After an introduction to the ALDREN project and a detailed overview on the ALDREN procedure, this paper presents the ALDREN Building Renovation Passport (BRP) and its development, the application of the BRP procedure to an Italian office building, and the results of each renovation step. Finally, remarks for future improvements of the BRP procedure are provided in the conclusions.

\section{ALDREN Project: Framework and Tools}

The main goal of ALDREN is to encourage investments and accelerate the movement towards a nearly Zero Energy nonresidential building stock across the EU, as targeted by 2050 to meet the Paris Agreement commitments [10]. To reach the European energy and climate objectives, the refurbishment of existing building stocks towards the deep renovation and NZEB levels is to be dramatically accelerated, in terms of both quantity (annual renovation rate) and quality (energy performance and overall quality).

A state-of-the-art review of the barriers for building renovation has revealed a lack of methodologies, which can promote sustainability objectives and assist various stakeholders during the design stage of building renovation/retrofitting projects. To this end, Decision Support System (DSS) or Multicriteria decision-making (MCDM) may help in evaluating and comparing different combined renovation scenarios, thus, promoting the regeneration of the building stock solving multiple-criteria decision problems. MCDM has become popular in energy planning as it enables the decision maker to pay attention to all the criteria available and make the appropriate decision as per the priority of the criteria.

In the latest years, a large spectrum of refurbishment tools and methods has been developed. Gohardani and Björk [11] present a valuable selection of those, highlighting that most of them only address a limited number of refurbishment criteria and they are valid for specific climatic contexts or local energy regulations. A multinational refurbishment, for example, should be considered, in order to capture the major disparities between the nations and to allow comparison and assessment. Besides that, different system approaches have also been developed for the analysis and problem solving in complex situations for sustainable renovations. Checkland and Scholes [12] distinguish between 'hard' and 'soft' systems thinking within the attempt to use system concepts to solve problems. Kamari et al. [13] provide a comprehensive overview on the refurbishment methods, which clearly highlights that developing a new sustainability decision-making support framework in a retrofitting context, is ultimately a very complex (due to different decision maker) and multidisciplinary task (within a sustainable perspective). Kamari, Jensen, Corrao, and Kirkegaard [14] investigated deeply MCDM design methodologies and processes for the building renovation field, and they identified a need for introducing three different decision-making levels to help stakeholders in the renovation process discuss their project "on the same level" and make transparent decisions in a rational order. Furthermore, the same authors introduced three sustainable retrofitting frameworks based on: (1) application of MCDM including either Multiple Attribute Decision MakingMADM methods: (2) Multiple Objective Decision Making-MODM, and (3) Holistic 
Multimethodology for Sustainable Building Renovation (HMSR), to help stakeholders overcome the problem formulated above [15].

In this context, ALDREN's overarching goal is, therefore, to raise confidence in deep energy renovation, answering the needs of key stakeholder groups involved in the renovation implementation chain.

An ALDREN Alliance has been set up to better specify their needs and include them in high quality protocols. Interactions between the ALDREN Consortium and the ALDREN Alliance have also allowed raising awareness on the co-benefits related to deep energy renovation and to the use of harmonized, reliable, and transparent European performance ratings and reporting tools. For this reason, the NZEB has been considered as the main target of ALDREN renovation strategies. The Commission Recommendation (EU) 2016/1318 [16] on guidelines for the promotion of nearly zero-energy buildings [17] has been taken as the main reference for nearly zero office buildings and recommended values for hotel NZEB were the basis for hotel NZEB definition [18].

After the official conclusion of the project (29 September 2020) [19], ALDREN reached the goal to become a modular and a flexible methodological framework based on a set of procedures (modules) that consist in implementing step-by-step operational protocols to assess the energy performance, Indoor Environmental Quality (IEQ, related to health and well-being) and financial value of buildings, before and after the energy renovation. ALDREN protocols rely on simulations and measurements based on best practices and the consistent use of CEN and ISO standards to ensure transparency and quality. ALDREN standalone modules produce a set of indicators that form consistent and holistic sustainability metrics. Alongside additional information, the indicators are reported in two dedicated and complimentary reporting tools that directly support the EU policies through the implementation of measures defined in the EPBD: The ALDREN European Voluntary Certification (EVC) and the ALDREN Building Renovation Passport (BRP).

\subsection{The ALDREN EVC}

The European Voluntary Certification Scheme (EVCS) has been introduced in Article 11(9) of the EPBD [20], and within the ALDREN project it is a backbone that supports the implementation of a common EVCS for nonresidential buildings based on CEN-ISO standards. The ALDREN EVC and EVC+ (extended version of the first), developed within the project, can be considered as a snapshot of the building performance, quality, and renovation potential at a given time. It has been created as a common content and template of European certificate, reporting all indicators together with the recommendations for improvement of energy performance towards the NZEB, with the link to more detailed ALDREN Building Renovation Passport (BRP). It is a valuable instrument fully compliant with the requirements on energy performance certificates in EPBD, which provides a sustainability metrics that could be used as eligibility criteria to mobilize private and public investments on deep renovation for existing buildings.

\subsection{The ALDREN BRP}

The ALDREN Building Renovation Passport is a complementary tool to the ALDREN EVC and EVC+, which provides, besides the general recommendations of EVC, a more detailed description of renovation activities in terms of time, costs, and technical performance.

Its dynamicity allows updating the BRP over the time along the renovation path. Principles, target, and users of the ALDREN BRP are synthetized and described in Table 1, clarifying for each of these three points their respective success factors.

The ALDREN BRP has been developed as a complementary tool to the Energy Performance Certificate (EPC), with the aim to increase owners' awareness about the current technical energy performance status of their building, as well as support them for its regular daily operation, coupled with a tailor made renovation roadmap that provides an assessment of three main Key Performance Indicators (KPIs): 
1. Energy savings triggered by ALDREN renovation actions $\left(\mathrm{kWh} / \mathrm{m}^{2}\right.$ year)

2. Renewable energy production triggered by ALDREN renovation actions $\left(\mathrm{kWh} / \mathrm{m}^{2}\right.$ year)

3. Investment costs of ALDREN renovation actions to reach KPI n.1 $\left(€\right.$ and $\left.€ / \mathrm{m}^{2}\right)$

Table 1. ALDREN Building Renovation Passport (BRP) success factors.

\begin{tabular}{|c|c|}
\hline \multicolumn{2}{|c|}{ Principles } \\
\hline COMPLIANCY & HARMONIZATION \\
\hline $\begin{array}{c}\text { Digital + paper instrument, complementary to the Energy } \\
\text { Performance Certificate (EPC) and European Voluntary } \\
\text { Certification (EVC), structured into two main elements: } \\
\text { A Building Logbook (BuildLog) and a Renovation } \\
\text { roadMap (RenoMap). }\end{array}$ & $\begin{array}{l}\text { Harmonized procedure for building data gathering } \\
\text { through the time, with a common language in a } \\
\text { cost-effective renovation plan. }\end{array}$ \\
\hline \multicolumn{2}{|l|}{ Target } \\
\hline BUILDING TYPOLOGY & ENERGY TARGET \\
\hline $\begin{array}{l}\text { Data sets for nonresidential buildings (hotels/offices). } \\
\text { BRP structure suitable also for residential: BuildLog + } \\
\text { RenoMap, with different detailed indicators in function of } \\
\text { building typology and owner needs. }\end{array}$ & $\begin{array}{l}\text { Follow the ALDREN protocols steps for BRP creation. } \\
\text { Collect users will and use it for the RenoMap creation. }\end{array}$ \\
\hline \multicolumn{2}{|l|}{ Users } \\
\hline OWNER/INVESTOR $(\mathrm{O})$ & ALDREN AUDITOR (AA) \\
\hline $\begin{array}{l}\text { Refer to a unique instrument. } \\
\text { Comprehension of real current state of the building. } \\
\text { Awareness on the renovation actions feasibility. }\end{array}$ & $\begin{array}{l}\text { Refer to the ALDREN protocols guidance for the BRP } \\
\text { creation based on step-by-step procedure. } \\
\text { Collect users will for the RenoMap creation. }\end{array}$ \\
\hline
\end{tabular}

One of the main important added values reached by the ALDREN BRP is the possibility to have two different versions of it, digital and paper, which facilitate the data comprehension by different possible users. The digital version includes all the data collected and calculated for the BRP procedure application, while the paper one is a portable version to increase the understanding of the core indicator values of the building by the majority of the BRP users regardless of their knowledge background in construction.

The creation of the ALDREN BRP follows a step-by-step procedure, as listed in Table 2. The five main steps are divided into subactivities in which is evident the importance given to the relationship between the owner and the ALDREN auditor.

Table 2. Step-by-step procedure for the ALDREN Building Renovation Passport (BRP).

\begin{tabular}{cccc}
\hline Step & Figures Involved & Subactivity & Action \\
\hline First contact interview & $\begin{array}{c}\text { ALDREN Auditor (AA) } \\
\text { Owner (O) }\end{array}$ & 1.1 & $\begin{array}{c}\text { O upstream interview. } \\
\text { AA presentation of the ALDREN } \\
\text { BRP modules to O. }\end{array}$ \\
\hline $\begin{array}{c}\text { Data collection and } \\
\text { ALDREN database creation }\end{array}$ & ALDREN Auditor (AA) & 1.2 & $\begin{array}{c}\text { AA collection of O will for the } \\
\text { selection of the BRP modules. }\end{array}$ \\
\hline & 2.1 & $\begin{array}{c}\text { AA detailed building inspection with } \\
\text { on-site survey in accordance with O. } \\
\text { Collection of all documentation } \\
\text { (digital, paper version) from different } \\
\text { sources (i.e., existing database or O). } \\
\text { Population of the selected BuildLog } \\
\text { modules with inputs collected for the } \\
\text { calculation of the protocols. }\end{array}$ \\
\hline
\end{tabular}


Table 2. Cont.

\begin{tabular}{|c|c|c|c|}
\hline Step & Figures Involved & Subactivity & Action \\
\hline $\begin{array}{l}3- \\
\text { ALDREN protocols } \\
\text { calculation and population } \\
\text { of the selected BuildLog } \\
\text { modules }\end{array}$ & ALDREN Auditor (AA) & 3.2 & $\begin{array}{l}\text { AA calculation of the selected } \\
\text { modules following the respective } \\
\text { protocols and using both simulations } \\
\text { and real data. } \\
\text { Integration of the ALDREN BuildLog } \\
\text { indicators for the selected modules } \\
\text { with the results of the protocols. } \\
\text { Outputs of the BuildLog modules } \\
\text { become inputs for the RenoMap } \\
\text { modules. }\end{array}$ \\
\hline $\begin{array}{l}4- \\
\begin{array}{l}\text { ALDREN RenoMap } \\
\text { definition }\end{array}\end{array}$ & $\begin{array}{c}\text { ALDREN Auditor (AA) + } \\
\text { Owner (O) }\end{array}$ & $\begin{array}{l}4.2 \\
4.3\end{array}$ & $\begin{array}{l}\text { AA first draft identification of the } \\
\text { Elementary Renovation Actions } \\
\text { (ERAs) within M7. } \\
\text { O final interview for discussion on } \\
\text { the ERAs draft of AA. } \\
\text { AA evaluation of ERAs agreed with } \\
\text { O within M8. } \\
\text { RenoMap creation with identification } \\
\text { of primary renovation packages, } \\
\text { long-term timeline, and Key } \\
\text { Performance Indicators (KPIs). }\end{array}$ \\
\hline $\begin{array}{c}5- \\
\text { Final contact: ALDREN } \\
\text { BRP delivery }\end{array}$ & $\begin{array}{c}\text { ALDREN Auditor (AA) + } \\
\text { Owner (O) }\end{array}$ & $\begin{array}{l}5.1 \\
5.2\end{array}$ & $\begin{array}{l}\text { AA creation of the ALDREN BRP } \\
\text { both in digital and paper version. } \\
O \text { and AA final meeting for the } \\
\text { ALDREN BRP delivery. }\end{array}$ \\
\hline
\end{tabular}

The main remark to be highlighted in this phase is the nonmandatory fulfillment and compilation of all the modules of the Building Logbook (BuildLog), since the selection depends on the owner's needs, will, and investment.

\section{The ALDREN BRP Structure}

The ALDREN BRP refers to travel passport analogy. Thus, the renovation path is considered as a journey on which the travelers (in this case owners or investors) are the main actors deciding the "stops" along the trip according to their will, financial availability, or other boundary conditions. The building owners and investors can choose which renovation actions to take, as well as when, how, and in which order the actions are carried out. The stamps of Figure 1 represent the Renovation "stop" in the travel analogy, which correspond also to the structure modules of the ALDREN BRP.

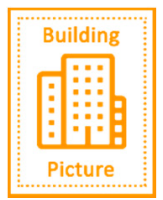

M1

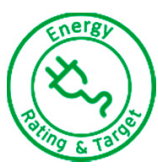

M2

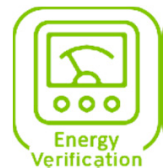

M3

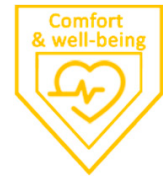

M4

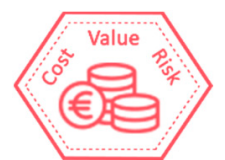

M5

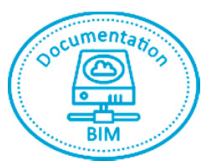

M6

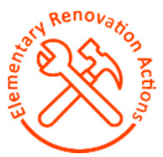

M7

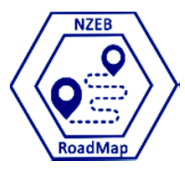

M8

Figure 1. Identification of each ALDREN BRP module (M) with a specific passport stamp.

The core structure of the passport foresees two main elements: Building Logbook (ALDREN BuildLog) and a tailored Renovation Roadmap (ALDREN RenoMap). The BuildLog informs building owners and managers about the current condition of the building in terms of its technical energy, indoor environmental quality (IEQ), and financial performance 
status. The RenoMap provides medium- and long-term renovation strategies to reach NZEB target to avoid lock-in effects.

Flexibility and modularity are the main important characteristics of the ALDREN BRP structure. The 8 BRP modules (corresponding to the 8 stamps, as shown in Figure 1) are connected but can be filled independently by an ALDREN auditor according to the renovation requests of the building owners. The digital version of the BRP is an Excel file composed by worksheets, which corresponds to the passport structure (6 sheets for the BuildLog modules and 2 for the RenoMap). In addition, there is the "read me" instruction sheet, which provides quick start guidance to the AA and the legend of the source compliancy of the indicators. Each module has an associated color corresponding to a specific source from which it has been selected or referred. The guidance allows the ALDREN auditor to understand the definition of the items in the modules and the method for calculating the standard values, depending on the reference.

At the end of the project, in order to support the dissemination and use of the ALDREN $\mathrm{BRP}$, a dedicated training for each module has been developed under the BuildUp platform and available also in the project website [1].

\subsection{ALDREN BuildLog}

Data collection, management, and digitalization are core topics for the European Commission. In the latest Communication COM (2020), 662 final on the Renovation Wave [21], it is underlined the importance to introduce a Digital Building Logbooks that will integrate all building related data provided by the upcoming Building Renovation Passports, Smart Readiness Indicators [22], Level(s) [23], and EPCs to ensure compatibility and integration of data throughout the renovation journey.

The comparative analysis, conducted within the ALDREN project, on the in-place initiatives on logbooks highlighted that they are all still facing many barriers for a further implementation or harmonization, such as: Costs implications, privacy and data management, fragmented regional approaches, static nature of the building logbook, administrative burden, and access to information [24].

For those reasons, the final version of the ALDREN BuildLog consists of six different modules (Table 3) with specific subcategories and respective protocols (detailed information can be found in the respective references listed in Table 3) to follow the implementation. The modules are independent from one another while the data are shared among them to optimize the information collection process. The BuildLog could facilitate access to structured information about how the building was originally designed, what changes have been made, and what its actual performance service level and planned maintenance is [25].

Table 3. Definition of the six ALDREN BuildLog modules.

\begin{tabular}{|c|c|c|c|}
\hline N. & Module Name & Subcategories & Description \\
\hline M1 & Building picture & $\begin{array}{c}\text { M1.1 Building feature } \\
\text { M1.2 Envelope } \\
\text { M1.3 Technical system data }\end{array}$ & $\begin{array}{l}\text { Outlines the current state of the building in } \\
\text { terms of geometry, location, documentation, } \\
\text { certification, technical components, } \\
\text { and general information on ownership. } \\
\text { ALDREN auditor collects the main information } \\
\text { without performing any calculation. Some of } \\
\text { the indicators collected will automatically be } \\
\text { used in other modules. }\end{array}$ \\
\hline
\end{tabular}


Table 3. Cont.

\begin{tabular}{ccc}
\hline N. & Module Name & Subcategories \\
\hline & & \\
& & M2.1 Features for EP assessment \\
& & M2.2 Building envelope-system \\
& & M2.3 Energy \\
M2 & Energy rating and & performance-calculated \\
& target [26] & M2.4 National EPC \\
& & M2.5 ALDREN EVC-rating \\
& & M2.6 Renewable energy \\
& & M2.7 Energy measured
\end{tabular}

Description

Overall indicators related to energy consumptions, system plants and energy rating. In some cases, the data can be collected and directly inserted by the ALDREN Auditor, since the value has been already evaluated, while in some other cases they have to be specifically calculated by the Auditor following the specific protocol of M2.

Reference standards and regulations: EU 2016/1318, 26 July 2016 [16], EN ISO 52000-1:2017 [27], EN ISO 52003-1:2017 [28], EN 16798-1:2018 [29], EN 15378-3:2017 [30].

Overall indicators related to the measured energy consumption, to evaluate the minimum gap between the predicted and real consumption of the building.

Data can be collected from the Building Management System (BMS) or from other systems of monitoring already in place.

M3 Energy verification [31]
M3.1 Quantity

M3.2 End use

M3.3 Weather data actual
The ALDREN auditor, using the Performance Verification and Measurement Tool (PVMT) developed within the project, could then evaluate the variance for each energy end use between standard condition and measured values.

Reference standards and methodologies: ASHRAE Standard 90.1 [32], QUANTUM performance test bench method [33].

Overall indicators related to the state of the building in terms of comfort and well-being for the calculation of the TAIL score, rating developed within the project to evaluate four main IEQ components:

Thermal-Acoustic-Indoor air quality-Luminous.

Overall indicators related to financial aspects, market trend and building value.

Overall indicators related to the existing materials for different issues, to check the availability and format of all the information.

The value of each indicator refers to the eventual availability of documentation; in positive case, it should be clarified in which format (digital, paper, or other) the indicator is available, eventually specifying the name and repository.

The ALDREN BuildLog can accompany the building manager and/or owner to collect the necessary building data, to have the information on the building's current state. This information is used to evaluate the possible renovation actions to be carried out on the building to reach the NZEB target. The main reference for a harmonized ALDREN NZEB 
definition at EU level is the Commission Recommendation EU 2016/1318 on guidelines for the promotion of nearly zero-energy buildings [16].

\subsection{ALDREN RenoMap}

As foreseen by the EPBD [20], Building Renovation Passports provides a roadmap for staged renovation over the lifetime of a building, helping owners and investors plan the best timing and scope for interventions. The ALDREN RenoMap aims to be the instrument that can support the ALDREN auditor and the building owner to identify (1) the potential Elementary Renovation Actions (ERAs) to be applied based on the current building conditions and the owner will, and (2) the timeline to follow and the respective costs with the final aim to reach a high/NZEB-compliant performance level. The RenoMap section of the ALDREN BRP is structured into two different modules (Table 4).

Table 4. Definition of the two ALDREN RenoMap modules.

N.

Identification and definition of a set of Elementary Renovation Actions (ERAs) related to the building specificities and actual potential in order to reach a high/NZEB-compliant performance level. The ALDREN Auditor has to identify the jump from the existing state to the renovated one (defined by levels from 0 to 4 ).

Design of a structured roadmap to support the decision-making process, defining the final timeline that summarizes the periods of renovation action implementation, including both the evaluated primary packages and the remaining ERAs.

Figure 2 presents the graphical results of the RenoMap, providing a list of the ERAs packages and the final sequence overtime.

\section{ALDREN $\lceil$ Reno $\mid$ Map} M8 - NZEB ROADMAP

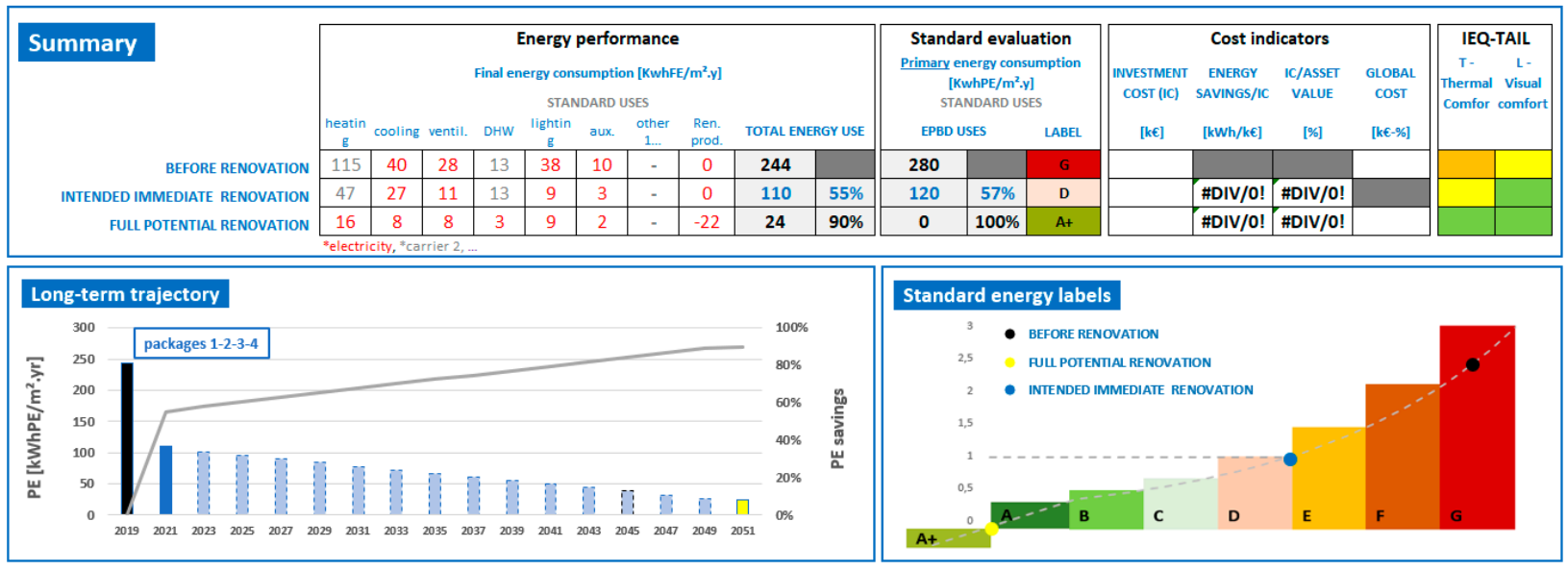

Figure 2. Summary part of the step-by-step ALDREN RenoMap template (values refer to a general example).

The summary depicts the assessment of the building at its initial state, after the intended renovation (current renovation project), and after the full potential renovation, respectively.

A first graph (on the bottom left in Figure 2) shows the temporal evolution of the building energy performance until 2050, from the initial stage to the fully renovated stage 
following the upcoming renovation actions. The energy-performance labels associated with the different building stages are calculated, respectively (second graph on the bottom right in Figure 2).

There are three main outcomes of the RenoMap application:

1. The identification of all the ERAs and the associated fully renovated building, which sets a final long-term objective and informs on the potential energy savings;

2. The primary packages evaluation, which provides guidance to the upcoming renovation and supports the short-term decision;

3. The long-term step-by-step timeline, displaying the renovation path for the following years according to replacement periods and opportunities.

Table 5 summarizes the main tasks of the RenoMap method.

Table 5. Summary of the ALDREN RenoMap protocol tasks.

\begin{tabular}{|c|c|c|c|c|c|}
\hline$\#$ & Task & Status & Description & Inputs & Outputs \\
\hline 1 & $\begin{array}{l}\text { Owner's } \\
\text { upstream } \\
\text { interview }\end{array}$ & Optional & $\begin{array}{l}\text { Collecting owner's remarks } \\
\text { and wishes. }\end{array}$ & Interviews guide & Internal note \\
\hline 2 & $\begin{array}{l}\text { Detailed } \\
\text { audit }\end{array}$ & Mandatory & $\begin{array}{l}\text { Referring to BRP LOGBOOK } \\
\text { to verify and complete initial } \\
\text { state description. Definition of } \\
\text { renovation actions. } \\
\text { NZEB-compliant level is } \\
\text { recommended if there is no } \\
\text { specific constraint. Evaluation } \\
\text { of obsolescence level. }\end{array}$ & $\begin{array}{c}\text { Evaluation Table of } \\
\text { ERAs v0 } \\
\text { Audit guide } \\
\text { Evaluation guide }\end{array}$ & $\begin{array}{c}\text { Evaluation Table } \\
\text { of ERAs v1 }\end{array}$ \\
\hline 3 & $\begin{array}{l}\text { Owner's } \\
\text { final } \\
\text { interview }\end{array}$ & Mandatory & $\begin{array}{l}\text { Having owner's feedback for } \\
\text { each of the identified ERAs } \\
\text { from the constituted list. } \\
\text { Completing ERAs Evaluation } \\
\text { Table. Identifying work } \\
\text { opportunities. }\end{array}$ & Evaluation guide & $\begin{array}{l}\text { Evaluation Table } \\
\text { of ERAs v2 }\end{array}$ \\
\hline 4 & $\begin{array}{l}\text { Evaluation } \\
\text { achieve- } \\
\text { ment }\end{array}$ & Mandatory & $\begin{array}{l}\text { Post-processing evaluation to } \\
\text { complete ERAs indicators in } \\
\text { ERAs Evaluation Table. }\end{array}$ & Evaluation guide & $\begin{array}{c}\text { Evaluation Table } \\
\text { of ERAs } \\
\text { consolidated } \\
\text { version }\end{array}$ \\
\hline 5 & $\begin{array}{l}\text { Reference } \\
\text { points } \\
\text { calculation }\end{array}$ & Mandatory & $\begin{array}{l}\text { Energy simulation of the } \\
\text { building before renovation. } \\
\text { Energy simulation with } \\
\text { potential renovated building } \\
\text { enhanced with all defined } \\
\text { ERAs. Filling in labels curve } \\
\text { on the template of the final } \\
\text { renovation roadmap. }\end{array}$ & $\begin{array}{l}\text { Building LOGBOOK } \\
\text { Evaluation Table of } \\
\text { ERAs } \\
\text { Step-by-step roadmap } \\
\text { v0 }\end{array}$ & $\begin{array}{l}\text { Step-by-step } \\
\text { roadmap v1 }\end{array}$ \\
\hline 6 & $\begin{array}{l}\text { Processing } \\
\text { of } \\
\text { renovation } \\
\text { strategy }\end{array}$ & Mandatory & $\begin{array}{l}\text { Identification of primary } \\
\text { renovation actions according } \\
\text { to obsolescence level, } \\
\text { owner will, energy efficiency, } \\
\text { and other indicators. } \\
\text { Constitution of packages with } \\
\text { interacting ERAs. }\end{array}$ & Strategy guidance & $\begin{array}{l}\text { Step-by-step } \\
\text { roadmap v2 }\end{array}$ \\
\hline
\end{tabular}


Table 5. Cont.

\begin{tabular}{|c|c|c|c|c|c|}
\hline \# & Task & Status & Description & Inputs & Outputs \\
\hline 7 & $\begin{array}{l}\text { Energy per- } \\
\text { formance } \\
\text { calculation } \\
\text { of primary } \\
\text { renovation } \\
\text { packages }\end{array}$ & Mandatory & $\begin{array}{l}\text { Energy simulation of the } \\
\text { building enhanced with the } \\
\text { selected packages of ERAs. }\end{array}$ & Strategy guidance & $\begin{array}{l}\text { Step-by-step } \\
\text { roadmap v3 }\end{array}$ \\
\hline 8 & $\begin{array}{l}\text { Definition } \\
\text { of the final } \\
\text { timeline }\end{array}$ & Mandatory & $\begin{array}{c}\text { Choice of the final renovation } \\
\text { configuration. Definition of } \\
\text { the final roadmap timeline } \\
\text { from packages evaluation, } \\
\text { remaining ERAs replacement } \\
\text { period and identified } \\
\text { opportunities. }\end{array}$ & $\begin{array}{c}\text { Step-by-step roadmap } \\
\text { v3 }\end{array}$ & $\begin{array}{l}\text { Step-by-step } \\
\text { roadmap v4 }\end{array}$ \\
\hline 9 & $\begin{array}{l}\text { Results } \\
\text { report for } \\
\text { decision } \\
\text { support }\end{array}$ & Mandatory & $\begin{array}{l}\text { Choice of the final renovation } \\
\text { configuration. Display of } \\
\text { outcomes. Viewing on the } \\
\text { labels and timeline curves. }\end{array}$ & $\begin{array}{c}\text { Step-by-step roadmap } \\
\text { v4 }\end{array}$ & $\begin{array}{l}\text { Step-by-step } \\
\text { roadmap } \\
\text { consolidated } \\
\text { version }\end{array}$ \\
\hline
\end{tabular}

\section{The ALDREN BRP Application: An Italian Office Pilot Case}

The ALDREN BRP procedure was applied to an Italian office building (the pilot case study). The renovation results for the modules selected by the building owner are presented in the following section.

\subsection{Building Description}

The Italian ALDREN pilot is an office building within the Lecco Campus of the Politecnico di Milano university, a few steps from the center of Lecco within the recovered and upgraded area of the former public hospital of the city, in via Ghislanzoni (Figure 3).

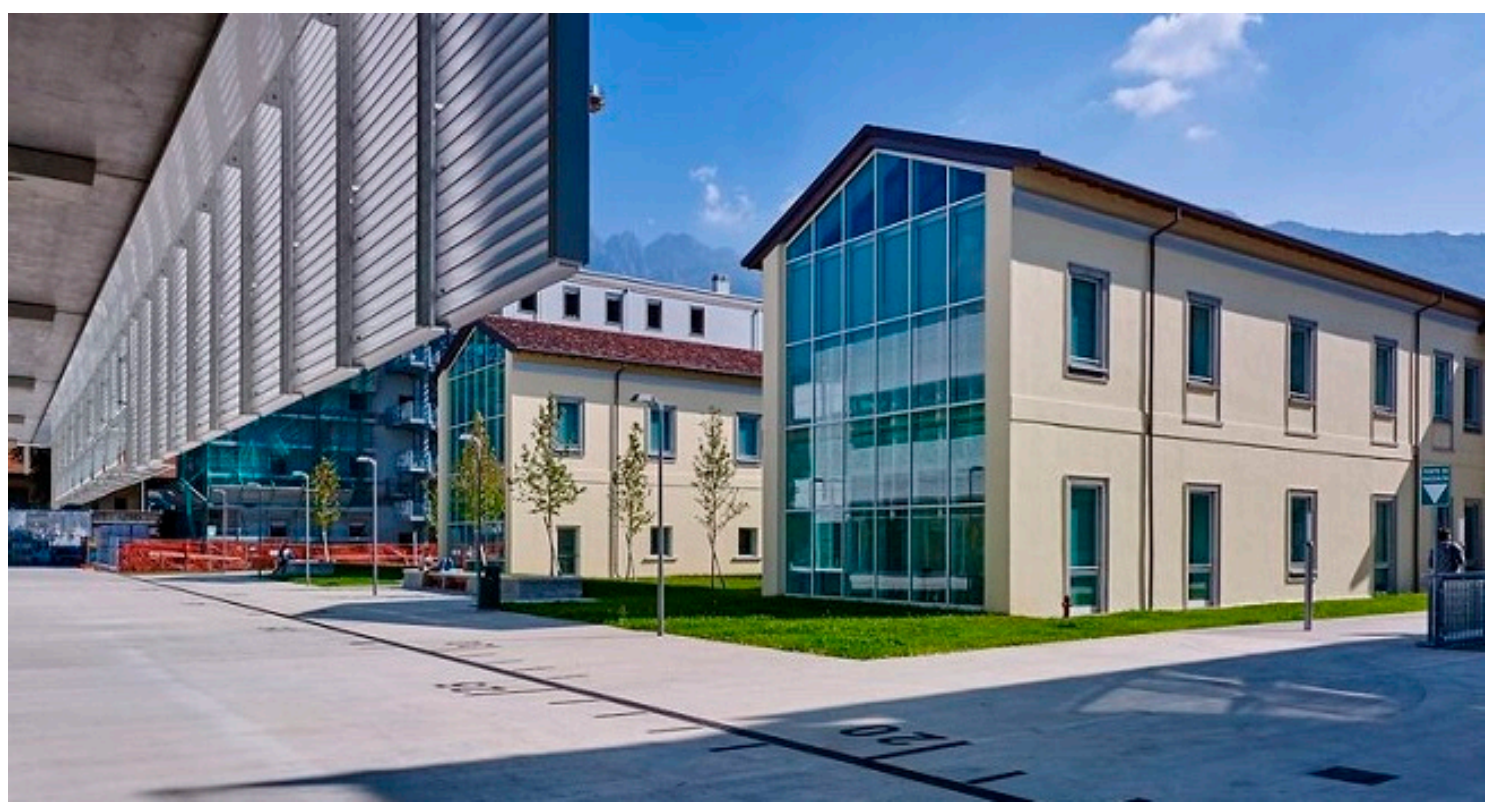

Figure 3. Building 8, Politecnico di Milano-Lecco Campus. 
The group of buildings was built in 1990 to form a comb shape. The studied building has two floors above the ground level, and the windows mark a regular rhythm in the façade. An intense refurbishment intervention of the building was carried out in 2014, which preserved the main structure, improved the envelope performance, upgraded the internal space distribution to fulfill the new functions, and integrated renewable energy sources to reduce its energy consumptions. In addition to the refurbishment intervention that has been put in place, the building was studied in the ALDREN project due to the interest of the building owners on developing its RenoMap to identify the necessary renovation actions to reach the NZEB target. The following tables provide a summary of the building's key features, in terms of construction technologies and system strategies (Table 6), and boundary climatic conditions (Table 7). According to these data, the nearest Typical Meteorological Year (TMY) for the hourly energy calculation was selected.

Table 6. Main features of the office Building 8 of Politecnico di Milano, Lecco Campus.

\begin{tabular}{|c|c|}
\hline Uses layout & Offices: Administration, university offices and meeting rooms. \\
\hline Envelope & $\begin{array}{l}\text { Walls with } 70-100 \mathrm{~mm} \text { layer of polystyrene fiber insulation. } \\
\text { Curtain walls made of aluminum profiles with uprights and crossbeams. Internal motorized } \\
\text { shading system with vertical sliding. Aluminum windows with thermal break. }\end{array}$ \\
\hline Systems & $\begin{array}{l}\text { AHU + VAV: All-air systems with partial recirculation Air Handling Units and systems with } \\
\text { Variable Air Volume. } \\
\text { FCAP: Air-water mixed systems with fancoil and primary air. } \\
\text { REX: Radiators and exhaust air system. }\end{array}$ \\
\hline
\end{tabular}

Table 7. Key data on the location of the office Building 8 of Politecnico di Milano, Lecco Campus.

$\begin{array}{cc}\text { Location } & \text { Lecco, IT } \\ \text { Altitude } & 214 \mathrm{~m} \\ \text { Latitude } & 45^{\circ} 51^{\prime} 23^{\prime \prime} 76 \mathrm{~N} \\ \text { Longitude } & 09^{\circ} 24^{\prime} 14^{\prime \prime} 04 \mathrm{E} \\ \text { Average annual temperature } & 12.3^{\circ} \mathrm{C} \\ \text { Average annual rainfall } & 118 \mathrm{~mm} \\ \text { Prevailing wind direction } & \text { South } \\ \text { Distance from the sea } & >40 \mathrm{~km} \\ \text { Average wind speed } & 0.9 \mathrm{~m} / \mathrm{s} \\ \text { Maximum wind speed } & 1.8 \mathrm{~m} / \mathrm{s} \\ \text { External design temperature } & -5{ }^{\circ} \mathrm{C} \\ \text { Conventional heating season } & 32.0^{\circ} \mathrm{C} \\ \text { Dry bulb outside temperature } & 23.6^{\circ} \mathrm{C} \\ \text { Wet bulb outside temperature } & 50 \% \\ \text { Relative humidity } & 80^{\circ} \mathrm{C} \\ \text { Daily temperature range } & 2383 \\ \text { Heating degree days } & \end{array}$

\subsection{Application of the ALDREN Step-by-Step Approach}

The application of the ALDREN BRP to the Italian office building followed the procedure described in Section 2 of the present paper, as outlined in particular in Table 2.

\subsubsection{First Contact Interview}

An initial meeting was held with the building owner to sign the agreement to apply the ALDREN protocol to the office building. On this occasion, as prescribed by subactivity \#1.3, the ALDREN auditor and the owner selected the BRP modules to be successively calculated: M1; M2; M4; M6; M7; and M8. 


\subsubsection{Data Collection and ALDREN Database Creation}

During the data collection step, the ALDREN auditor held different meetings with the facility management staff and the owner to check, revise, and organize all the technical documents necessary for the ALDREN protocol application.

For the measurements of the different indicators required for the M4 protocol, a monitoring campaign started in November 2019 for the duration of one month. It was difficult to collect data on the energy consumption per energy vector, since the plant systems covered the energy demand of more buildings with different functions altogether, and there was no submetering system that allows to derive the data for the single pilot case building.

\subsubsection{ALDREN Protocols Calculation and Population of the Selected BuildLog Modules}

The calculation software used to draft the energy modeling was TRNSYS 18 [36], a complete, modular, and expansible simulation environment for the transient simulation of thermal systems, including multizone buildings. The following steps were followed to process the data: (i) 3D modeling of the building and identification of thermal zones, (ii) setting of the characteristics related to the building, through the TRNBuild plug-in, (iii) processing and simulation of the data entered, by the use of Simulation Studio plug-in.

The entire model of the building is presented in Figure 4 and it was divided into eleven thermal zones for the calculations.

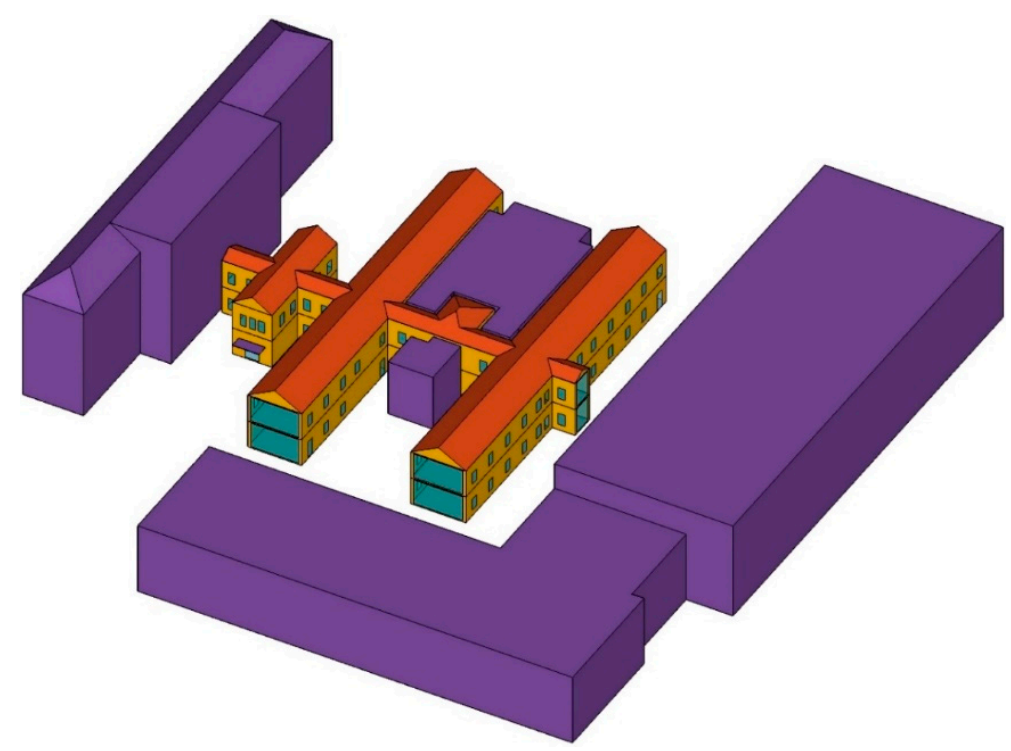

Figure 4. TRNSYS 3D model of the Building 8, Politecnico di Milano-Lecco Campus. All the volumes near the building are represented in purple: They have not been identified as thermal zones but as simple shading bodies. The parts in blue are the windows, the ones in yellow are the external walls, and the red ones represent the roof.

The envelope technologies used for the energy modeling of the office building are defined in Tables 8 and 9 . The air tightness/infiltration rate $(0.251 / \mathrm{h})$ was obtained through on-site measurements.

\subsubsection{ALDREN RenoMap Definition}

After the evaluation of the current state of the building in 2020, and considering the refurbishment made during the first renovation in 2014 from the original construction of 1900 , the elementary renovation actions were identified with the main goal of improving the internal comfort and reaching the NZEB target, consequently reducing consumptions. All the packages of renovation actions identified were selected combining the owners' needs and the obsolescence level of the building. The packages identified within the RenoMap are summarized in Table 11. 
Table 8. Characteristics and main parameters of the opaque building envelope.

\begin{tabular}{cccccc}
\hline & External Wall & $\begin{array}{c}\text { Floor } \\
\text { (Unheated) }\end{array}$ & Floor (Heated) & Pitched Roof & Roof \\
\hline Thermal transmittance & $0.287 \mathrm{~W} / \mathrm{m}^{2} \mathrm{~K}$ & $0.265 \mathrm{~W} / \mathrm{m}^{2} \mathrm{~K}$ & $1.220 \mathrm{~W} / \mathrm{m}^{2} \mathrm{~K}$ & $0.292 \mathrm{~W} / \mathrm{m}^{2} \mathrm{~K}$ & $0.190 \mathrm{~W} / \mathrm{m}^{2} \mathrm{~K}$ \\
Thickness & $746 \mathrm{~mm}$ & $326 \mathrm{~mm}$ & $340 \mathrm{~mm}$ & $181 \mathrm{~mm}$ & $321 \mathrm{~mm}$ \\
External temperature & $-5^{\circ} \mathrm{C}$ & $7.5^{\circ} \mathrm{C}$ & - & $2.5^{\circ} \mathrm{C}$ & $-5^{\circ} \mathrm{C}$ \\
Surface mass & $1380 \mathrm{~kg} / \mathrm{m}^{2}$ & $487 \mathrm{~kg} / \mathrm{m}^{2}$ & $490 \mathrm{~kg} / \mathrm{m}^{2}$ & $184 \mathrm{~kg} / \mathrm{m}^{2}$ & $80 \mathrm{~kg} / \mathrm{m}^{2}$ \\
Periodic thermal & $0.006 \mathrm{~W} / \mathrm{m}^{2} \mathrm{~K}$ & $0.028 \mathrm{~W} / \mathrm{m}^{2} \mathrm{~K}$ & $0.214 \mathrm{~W} / \mathrm{m}^{2} \mathrm{~K}$ & $0.152 \mathrm{~W} / \mathrm{m}^{2} \mathrm{~K}$ & $0.167 \mathrm{~W} / \mathrm{m}^{2} \mathrm{~K}$ \\
transmittance & 0.021 & 0.106 & 0.175 & 0.521 & 0.886 \\
Decrement factor & $18.0 \mathrm{~h}$ & $12.0 \mathrm{~h}$ & $10.5 \mathrm{~h}$ & $5.5 \mathrm{~h}$ & $3.9 \mathrm{~h}$ \\
Time shift & & &
\end{tabular}

Table 9. Characteristics and main parameters of the building glazing elements.

\begin{tabular}{ccc}
\hline & Window & Curtain Wall \\
\hline Thermal transmittance & $1.535 \mathrm{~W} / \mathrm{m}^{2} \mathrm{~K}$ & $1.355 \mathrm{~W} / \mathrm{m}^{2} \mathrm{~K}$ \\
Thermal transmittance of the glass & $1.100 \mathrm{~W} / \mathrm{m}^{2} \mathrm{~K}$ & $1.000 \mathrm{~W} / \mathrm{m}^{2} \mathrm{~K}$ \\
Thermal transmittance of the frame & $2.200 \mathrm{~W} / \mathrm{m}^{2} \mathrm{~K}$ & $2.340 \mathrm{~W} / \mathrm{m}^{2} \mathrm{~K}$ \\
Linear conductance of the spacer & $0.100 \mathrm{~W} / \mathrm{m}^{2} \mathrm{~K}$ & $0.100 \mathrm{~W} / \mathrm{m}^{2} \mathrm{~K}$ \\
Emissivity of the glass & 0.900 & 0.900 \\
Solar factor & 0.670 & 0.670 \\
Shape factor of the frame & 0.810 & 0.870 \\
\hline
\end{tabular}

Table 10 lists the general settings considered in the building energy model.

Table 10. Internal loads and schedules of Building 8, Politecnico di Milano-Lecco Campus.

$\begin{array}{cc}\text { Occupation range } & \text { Mon-Fri 8:00-18:00 } \\ \text { Heating set-point temperature } & \text { On: } 20^{\circ} \mathrm{C}-\text { Off: } 16^{\circ} \mathrm{C} \\ \text { Cooling set-point temperature } & \text { On: } 26^{\circ} \mathrm{C}-\text { Off: } 30^{\circ} \mathrm{C} \\ \text { Lighting schedule } & \text { Mon-Fri 8:00-18:00 } \\ \text { Ventilation schedule } & \text { Mon-Fri 8:00-18:00 } \\ \text { Ventilation intensity } & 1.44 \mathrm{~kg} / \mathrm{h} \mathrm{m} \mathrm{m}^{2} \\ \text { Nominal occupancy } & 0.1 \mathrm{people} / \mathrm{m}^{2} \\ \text { Internal loads—occupation } & 10.6 \mathrm{~W} / \mathrm{m}^{2} \\ \text { Internal loads-inoccupation } & 9.6 \mathrm{~W} / \mathrm{m}^{2}\end{array}$

Table 11. Identification of the ERAs sets for Building 8, Politecnico di Milano-Lecco Campus, by priority level defined according to owner wills and technical obsolescence.

\begin{tabular}{cccc}
\hline Priority Level & Renovation Actions & $\begin{array}{c}\text { Replacement } \\
\text { Period/Opportunity }\end{array}$ & Motivations \\
\hline 1a-1b & $\begin{array}{c}\text { Heating/cooling automatic control } \\
\text { Lighting system improvement } \\
\text { Lighting automatic control system } \\
\text { Implementation of PV system }\end{array}$ & $2020-2021$ & High economy \\
& $\begin{array}{c}\text { North windows replacement: Triple } \\
\text { glazing }\left(\mathrm{U}=0.8 \mathrm{~W} / \mathrm{m}^{2} \mathrm{~K}\right)\end{array}$ & $2025-2030$ & Owner will investment \\
& $\begin{array}{c}\text { South windows replacement: Double } \\
\text { glazing }\left(\mathrm{U}=1.1 \mathrm{~W} / \mathrm{m}^{2} \mathrm{~K}\right) \\
\text { Ventilation system replacement } \\
\text { Ventilation controls implementation }\end{array}$ & $2030-2040$ & High economy \\
& efficiency-potentially immediate \\
\hline
\end{tabular}


Table 11. Cont.

\begin{tabular}{cccc}
\hline Priority Level & Renovation Actions & $\begin{array}{c}\text { Replacement } \\
\text { Period/Opportunity }\end{array}$ & Motivations \\
\hline+4 & $\begin{array}{c}\text { Heat pump replacement } \\
\text { Amelioration of PV system }\end{array}$ & $2034-2040$ & High economy \\
efficiency-potentially immediate
\end{tabular}

\section{Results}

The application of the selected modules (M1; M2; M4; M6; M7; and M8) led to the creation of the ALDREN BRP in both digital and paper versions. Since the results of Modules 2, 4, and 8 are presented in the dedicated following subsections of the present manuscript, for brevity, Figure 5 shows only the cover and the KPIs page of the ALDREN BRP paper version.
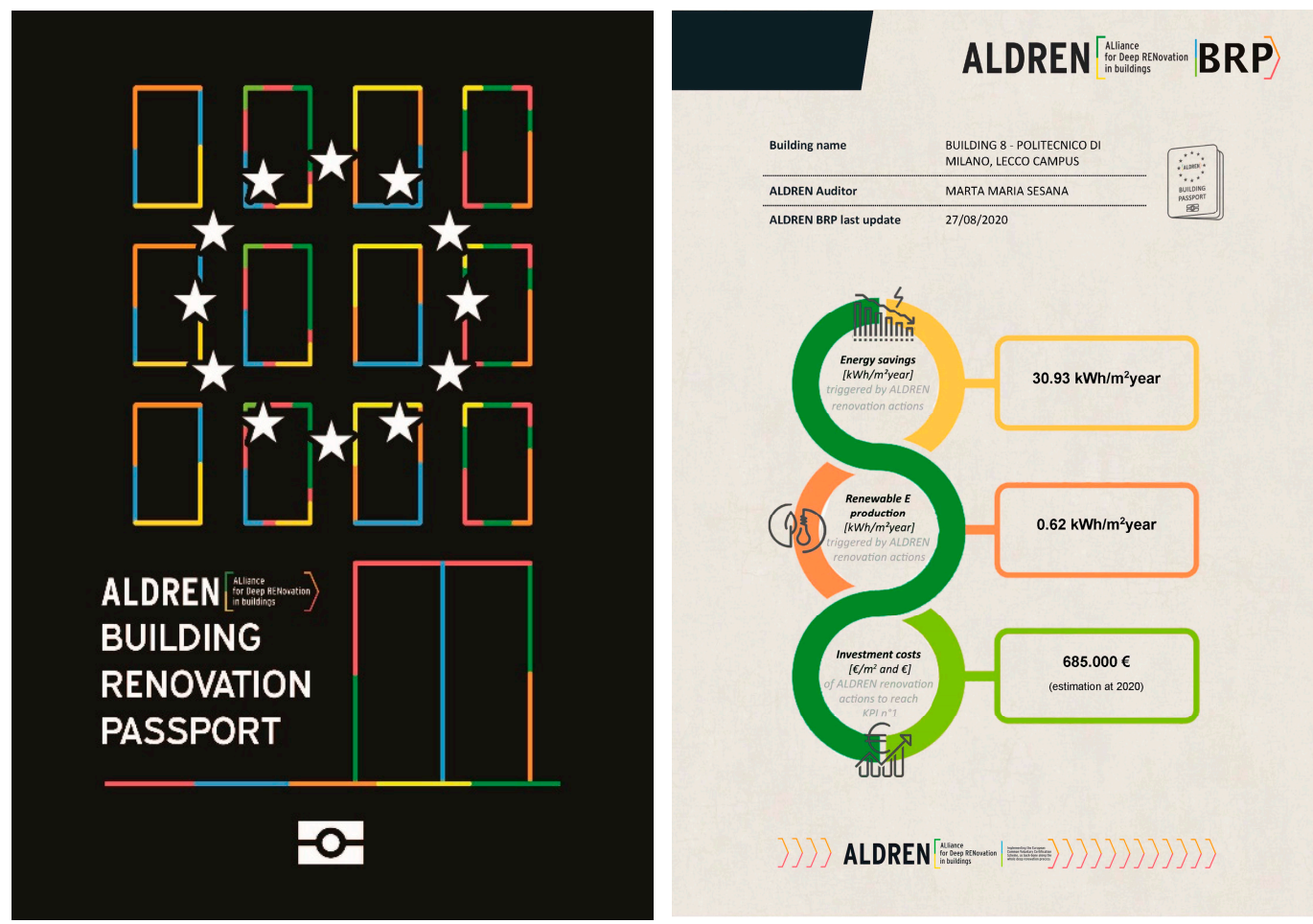

Figure 5. Cover and KPIs page of the ALDREN BRP Paper version for Building 8, Politecnico di Milano-Lecco Campus.

In particular, for the sake of paper comprehension and brevity, the following subsections focus only on the presentation of the core indicators results related to energy (M2), well-being (M4), and renovation actions (M7-M8) to address the three main ALDREN Key Performance Indicators (KPIs).

\subsection{Key Performance Indicators (KPIs)}

The three ALDREN BRP KPIs were evaluated according the ALDREN RenoMap under standard conditions and are summarized in Table 12.

The RenoMap packages were identified according to the owners' needs and the obsolescence level of the building. The cost of the renovation actions according to the reference costs from construction companies and market values databases was calculated but was not considered as an impact factor for the study. 
Table 12. ALDREN KPIs results of the Italian case with the RenoMap full packages application.

\begin{tabular}{cc}
\hline KPI & Values \\
\hline $\begin{array}{c}\text { \#1-Maximum energy savings triggered by ALDREN } \\
\text { recommended renovation actions }\left(\mathrm{kWh} / \mathrm{m}^{2} \text { year }\right)\end{array}$ & $30.49 \mathrm{kWh} / \mathrm{m}^{2}$ year \\
\hline $\begin{array}{c}\text { \#2-Maximum renewable energy production triggered by } \\
\text { ALDREN renovation project }\left(\mathrm{kWh} / \mathrm{m}^{2} \text { year }\right)\end{array}$ & $0.92 \mathrm{kWh} / \mathrm{m}^{2}$ year \\
\hline \#3-Investment costs of renovation actions to reach the & $685,000 €$ \\
performance target of KPI $\# 1\left(€\right.$ and $\left.€ / \mathrm{m}^{2}\right)$ & $151.08 € / \mathrm{m}^{2}$ \\
\hline
\end{tabular}

\subsection{Energy Rating and Target (M2)}

The application of the relative protocol calculations led to the results on the energy rating and target as represented in Figure 6.

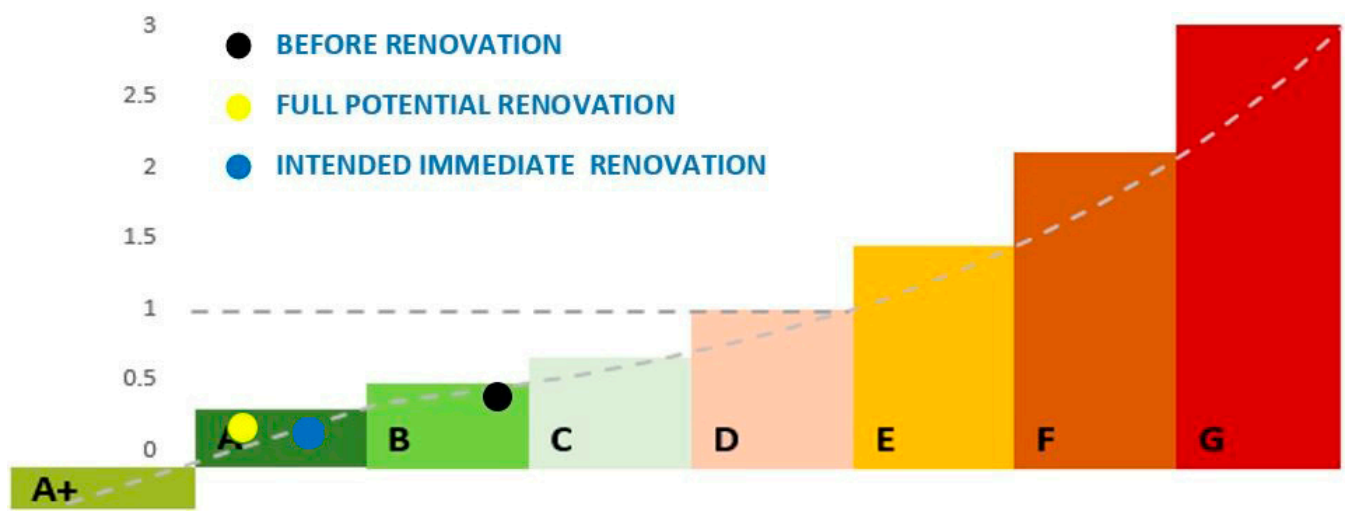

Figure 6. Energy rating results before and after the renovation on Building 8, Politecnico di MilanoLecco Campus.

The energy rating, according to the M2 protocol, is equal to class B for the building at the current state (corresponding to the "before renovation" in the graph above), and class A with the full ERAs packages application (corresponding to the "full potential renovation" in Figure 6).

\subsection{Comfort and Well-Being (M4)}

The indoor environmental quality (IEQ) level of the building was assessed by the TAIL index according to the ALDREN-TAIL protocol [37-39]. The TAIL index evaluates the quality levels of four indoor environmental quality (IEQ) components, i.e., thermal environment (T), acoustic environment (A), indoor air quality (I), and luminous environment (L), as well as the overall IEQ level of the building.

The TAIL index consists of 12 IEQ indicators, such as the air temperature, sound pressure level, formaldehyde concentration, and luminous level. The indicators were all assessed objectively by measurements. The results of the TAIL index for the Italian office building are shown in Figure 7.

The TAIL results for the building "before renovation" were calculated following the TAIL protocol and referring to the measurement campaign and the IEQ level of the building at the current state. The TAIL results for the building "after renovation" refer to evaluations based on simulation analysis.

\subsection{Elementary Renovation Actions (M7) and NZEB Roadmap (M8)}

The NZEB RoadMap of the office building was structured from the Elementary Renovation Actions (ERAs) packages identified and listed in Table 12. Figure 8 represents the temporal evolution of the building energy performance until 2050, from the current stage to the fully renovated building after applying the renovation packages. 


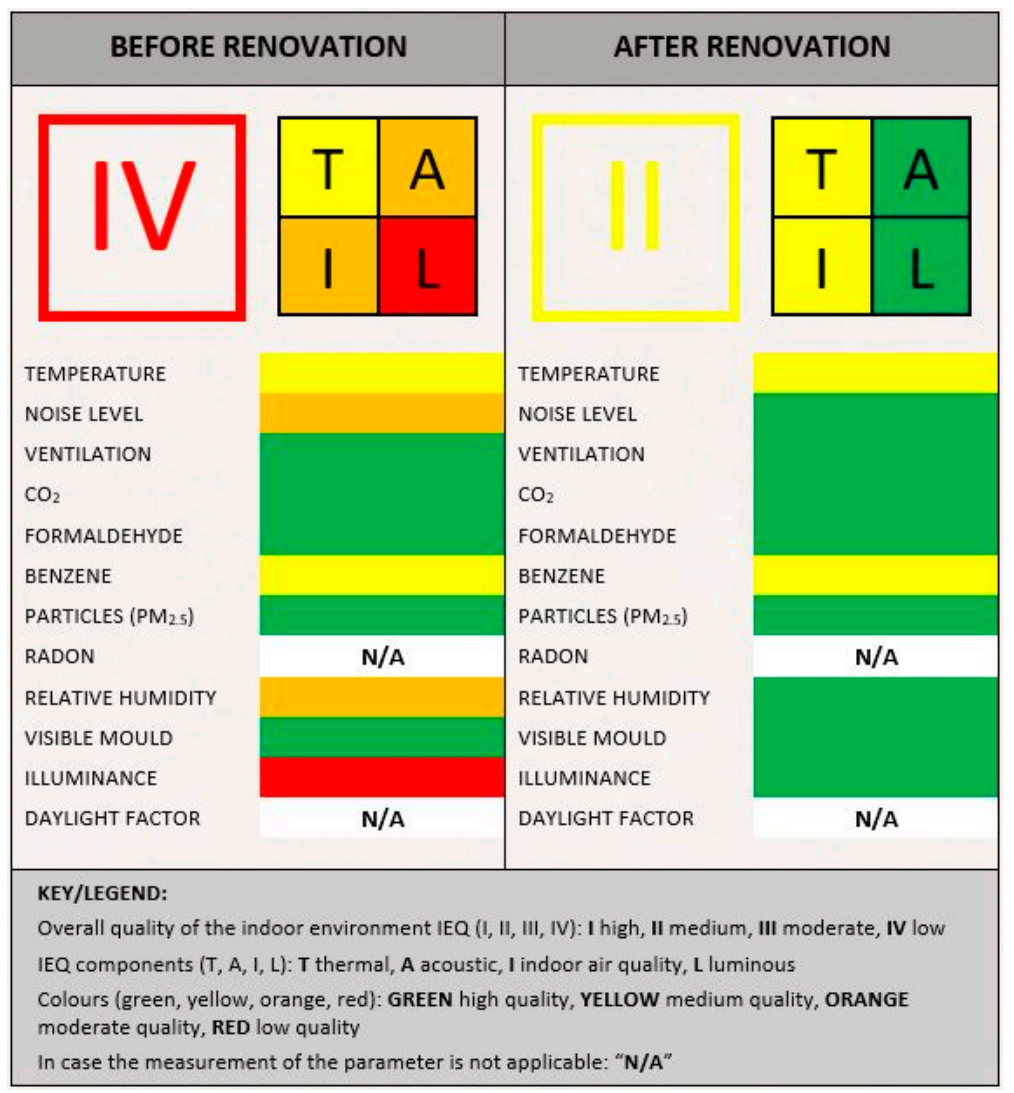

Figure 7. TAIL results before (left) and after (right) the renovation on Building 8, Politecnico di Milano-Lecco Campus.

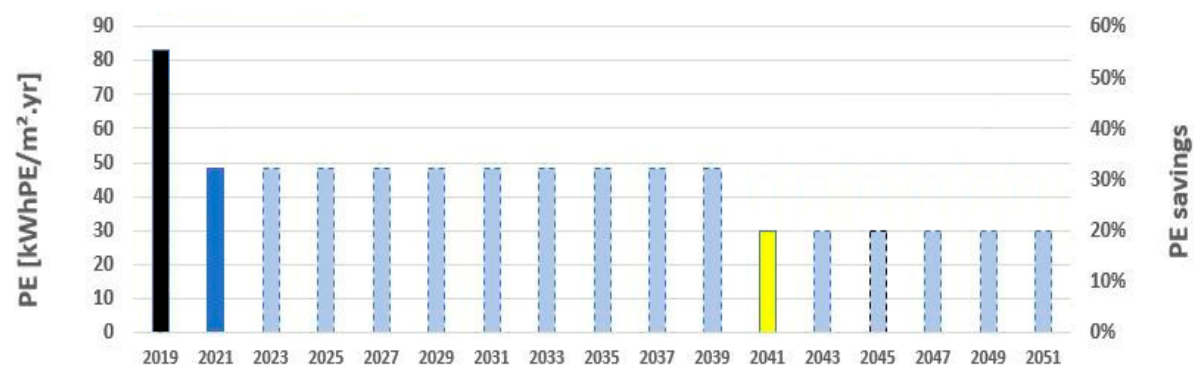

Figure 8. Step-by-step roadmap result for Building 8, Politecnico di Milano-Lecco Campus.

\section{Conclusions}

The research contributions of ALDREN protocol in comparison to the existing one for sustainable renovations of nonresidential buildings are: (i) the development of an overall methodological framework consisting of four standalone modules to assess the energy performance, Indoor Environmental Quality, and financial value of buildings with two reporting tools (EU Voluntary Certificate, Building Renovation Passport); (ii) the introduction of a specific index, called ALDREN-TAIL, to rate the Indoor Environment Quality (IEQ) of buildings before and after renovation, focusing on four key components: Thermal environment (T), Acoustic environment (A), Indoor air quality (I), Luminous environment (L), and (iii) the development of a "Performance Verification Tool" (PVT) to compare predicted and actual performance at different levels of granularity.

Referring then to the ALDREN BRP development and application to some real cases and, in particular, to the one presented in this paper, some weaknesses and strengths 
are listed as follows, to identify open issues and points that may be implemented in future studies.

- The implementation and use of the ALDREN BRP can support the reduction of administrative burden for owners and professionals and avoid the lock-in effect reducing the information asymmetries, but it needs a common language and a central European repository for reliable data on the building stock, its energy performance, and available financial incentives.

- The ALDREN BuildLog is a first trial of the Digitalized Building Logbook that could be adapted to other building typologies to cover the needs of the EU building stock.

- The ALDREN RenoMap identifies more realistic operation and maintenance renovation actions compared to the current EPC recommendations, but its development requires a specific background and training preparation in order to fulfill the evaluation according to the ALDREN protocols.

Although the work presented in this paper is informed by the partial application of the ALDREN framework and some parts of the methodology are still incomplete, we accept that its development is in line with the renovation wave initiative in scope and we hope it can contribute to building passport and certification tools development more comparable and harmonized across the EU.

Further development of the framework will include more explicit examination and application of some economics and IEQ indicators, which could be calculated thanks to simulation to improve the renovation packages' evaluation process. According to the organization of the RenoMap process, Excel is probably not the most suitable and efficient tool. For a wider development, a more web-based application may be needed to make calculations automated.

Author Contributions: Conceptualization, M.M.S. and G.S.; methodology, M.M.S. and G.S.; validation, M.M.S., D.B., C.M. and W.W.; formal analysis, M.M.S. and C.M.; investigation, M.M.S.; writing—original draft preparation, D.B. and M.M.S.; writing—review and editing, M.M.S., D.B., C.M., W.W. and G.S.; visualization, D.B.; supervision, G.S. All authors have read and agreed to the published version of the manuscript.

Funding: This research was funded by European Union H2020 Work Programme, grant number 754159 .

Data Availability Statement: Publicly available datasets were analyzed in this study. This data can be found here: https:/ /aldren.eu/project/polimi/.

Acknowledgments: The work presented in this paper is part of the results obtained within the ALDREN project. The entire ALDREN project team should be acknowledged for the fruitful discussions and support. For more information on the project and partners, www.aldren.eu/.

Conflicts of Interest: The authors declare no conflict of interest.

\section{References}

1. ALDREN-ALliance for Deep RENovation in Buildings. Available online: https://aldren.eu/ (accessed on 10 December 2020).

2. Sesana, M.M.; Salvalai, G. A Review on Building Renovation Passport: Potentialities and Barriers on Current Initiatives. Energy Build. 2018, 173, 195-205. [CrossRef]

3. European Commission. Questions and Answers on the Renovation Wave. Available online: https://ec.europa.eu/commission/ presscorner/detail/en/qanda_20_1836 (accessed on 14 October 2020).

4. Roscini, A.V.; Rapf, O.; Kockat, J. Contributions from the Building Sector to A Strengthened 2030 Climate Target; Buildings Performance Institute Europe (BPIE): Brussels, Belgium, 2020.

5. Economidou, M.; Todeschi, V.; Bertoldi, P.; D'Agostino, D.; Zangheri, P.; Castellazzi, L. Review of 50 years of EU energy efficiency policies for buildings. Energy Build. 2020, 225, 110322. [CrossRef]

6. Ruggeri, A.G.; Gabrielli, L.; Scarpa, M. Energy Retrofit in European Building Portfolios: A Review of Five Key Aspects. Sustainability 2020, 12, 7465. [CrossRef]

7. Dirutigliano, D.; Delmastro, C.; Moghadam, S.T. A multi-criteria application to select energy retrofit measures at the building and district scale. Therm. Sci. Eng. Prog. 2018, 6, 457-464. [CrossRef] 
8. Løken, E. Use of multicriteria decision analysis methods for energy planning problems. Renew. Sustain. Energy Rev. 2007, 11, 1584-1595. [CrossRef]

9. Ascione, F.; Bianco, N.; Mauro, G.M.; Napolitano, D.F.; Vanoli, G.P. A Multi-Criteria Approach to Achieve Constrained CostOptimal Energy Retrofits of Buildings by Mitigating Climate Change and Urban Overheating. Climate 2018, 6, 37. [CrossRef]

10. United Nations. Paris Agreement to the United Nations Framework Convention of Climate Change 12 December 2015, The authentic Text of the Paris Agreement in All Six Official UN languages Can Be Found Here. Available online: https: / / treaties.un.org/doc/Treaties/2016/02/20160215\%2006-03\%20PM/Ch_XXVII-7-d.pdf. (accessed on 22 December 2020).

11. Gohardani, N.; Björk, F. Sustainable refurbishment in building technology. Smart Sustain. Built Environ. 2012, 1, $241-252$. [CrossRef]

12. Kamari, A.; Corrao, R.; Kirkegaard, P.H. Sustainability focused decision-making in building renovation. Int. J. Sustain. Built Environ. 2017, 6, 330-350. [CrossRef]

13. Kamari, A.; Corrao, R.; Kirkegaard, P.H. Soft Systems Methodology in Action; John Wiley \& Sons: Chichster, UK, 1990.

14. Kamari, A.; Jensen, S.R.; Corrao, R.; Kirkegaard, P.H. Towards a holistic methodology in sustainable retrofitting: Theory, implementation and application. In Proceedings of the World Sustainable Built Environment Conference (WSBE 2017), Hong Kong, China, 5-7 June 2017; pp. 702-708.

15. Kamari, A.; Jensen, S.R.; Corrao, R.; Kirkegaard, P.H. A holistic Multi-methodology for Sustainable Renovation: Theory, implementation and application. Int. J. Strateg. Prop. Manag. 2019, 23, 50-64. [CrossRef]

16. European Commission, Commission Recommendation (EU). 2016/1318 of 29 July 2016 on Guidelines for the Promotion of Nearly Zero-Energy Buildings and Best Practices to Ensure That, by 2020, All New Buildings Are Nearly Zero-Energy Buildings; L 208/46; Official Journal of the European Union: Brussels, Belgium, 2016.

17. Buso, T.; Corgnati, S.P.; Derjanecz, A.; Kurnitski, J.; Litiu, A. Nearly Zero Energy hotels. REHVA J. 2015, 6, 28-32.

18. Kurnitski, J.; Buso, T.; Corgnati, S.P.; Derjanecz, A.; Litiu, A. nZEB definitions in Europe. REHVA J. 2014, 2, 6-9.

19. ALDREN Final Conference. Available online: https://aldren.eu/aldren-final-conference/ (accessed on 3 November 2020).

20. European Parliament and Council of the European Union. Directive (EU) 2018/844 of the European Parliament and of the Council of 30 May 2018 Amending Directive 2010/31/EU on the Energy Performance of Buildings and Directive 2012/27/EU on Energy Efficiency. PE/4/2018/REV/1; L 156/75; Official Journal of the European Union: Brussels, Belgium, 2018.

21. European Commission. A Renovation Wave for Europe-Greening our Buildings, Creating Jobs, Improving Lives. In Communication from the Commission to the European Parliament, the Council, the European Economic and Social Committee and the Committee of the Regions; European Commission: Brussels, Belgium, 2020.

22. SRI. Smart Readiness Indicator for Buildings. Available online: https://smartreadinessindicator.eu/ (accessed on 1 December 2020).

23. Dodd, N.; Cordella, M.; Traverso, M.; Donatello, S. Level(s)—A common EU framework of core sustainability indicators for office and residential buildings, Part 3: How to make performance assessments using Level(s). JRC Sci. Hub. Publ. 2017. [CrossRef]

24. Sesana, M.M.; Salvalai, G.; Ligier, S.; Rivallain, M. The ALDREN Building Renovation Passport for Non-Residential buildings: A modular digital instrument to support the Renovation Wave. REHVA J. 2020, 57, 35-41.

25. Sesana, M.M.; Rivallain, M.; Salvalai, G. Overview of the Available Knowledge for the Data Model Definition of a Building Renovation Passport for Non-Residential Buildings: The ALDREN Project Experience. Sustainability 2020, 12, 642. [CrossRef]

26. Bendžalová, J. European Common Voluntary Certification Scheme and energy ratings. REHVA J. 2020, 57, 11-17.

27. EN ISO 52000-1:2017 Energy Performance of Buildings—Overarching EPB Assessment_Part 1: General Framework and Procedures. 2017. Available online: https:/ / www.iso.org/standard /65601.html (accessed on 22 December 2020).

28. EN ISO 52003-1:2017 Energy Performance of Buildings—Indicators, Requirements, Ratings and Certificates-Part 1: General Aspects and Application to the Overall Energy Performance. 2017. Available online: https://www.iso.org/standard/65662.html (accessed on 22 December 2020).

29. EN 16798-1:2019 Energy Performance of Buildings_-Ventilation of Buildings_Part 1: Indoor Environmental Input Parameters for Design and Assessment of Energy Performance of Buildings Addressing Indoor Air Quality, Thermal Environment, Lighting and Acoustics. 2019. Available online: https:/ / standards.iteh.ai/catalog/standards/cen/b4f68755-2204-4796-854a-56643dfcfe89/en-16798-1-2019 (accessed on 22 December 2020).

30. EN 15378-3:2017-Energy Performance of Buildings_-Heating and DHW Systems in Buildings_Part 3: Measured Energy Performance. 2017. Available online: https:/ / standards.iteh.ai/catalog/standards/cen/b960194e-4bf8-42a5-8421-ab6ec4e1d598/en-153783-2017 (accessed on 22 December 2020).

31. Cohen, R.; Waring, G.; Ansari, S. Closing the energy gap in renovations of offices and hotels. REHVA J. 2020, 57, 18-21.

32. ASHRAE Standard 90.1, Energy Standard for Buildings Except Low-Rise Residential Buildings. 2016. Available online: https: / / ashrae.iwrapper.com/ASHRAE_PREVIEW_ONLY_STANDARDS/STD_90.1_2016_IP (accessed on 22 December 2020).

33. Mechanical and Electrical Engineering Working Party of National, Regional and Local Authorities (AMEV) for QUANTUM Project. In Technical Monitoring as an Instrument for Quality Assurance; AMEV Recommendation n.135, August 2017; Available online: https:/ / www.amev-online.de/AMEVInhalt/Funktionsnavigation/Erlasse/ (accessed on 22 December 2020).

34. Wei, W.; Mandin, C.; Wargocki, P. Application of ALDREN-TAIL index. REHVA J. 2020, 57, $22-24$.

35. Greslou, O.; Bendžalová, J. Linking ALDREN's energy and IEQ performance assessments to financial value of buildings. REHVA J. 2020, 57, 26-30. 
36. TRNSYS. Transient Systems Simulation Homepage. Available online: http:/ / www.trnsys.com (accessed on 1 September 2012).

37. Wei, W.; Wargocki, P.; Zirngibl, J.; Bendžalová, J.; Mandin, C. Review of parameters used to assess the quality of the indoor environment in Green Building certification schemes for offices and hotels. Energy Build. 2020, 209, 109683. [CrossRef]

38. Wargocki, P.; Mandin, C.; Wei, W.; Espigares, C.; Bendžalová, J.; Greslou, O.; Rivallain, M.; Zirngibl, J. Assessment of indoor environmental quality (IEQ) in offices and hotels undergoing deep energy renovation-The ALDREN method. REHVA J. 2019, $54,49-53$.

39. Wargocki, P.; Wei, W.; Anton, R.; Bendžalová, J.; Espigares, C.; Gerard, C.; Greslou, O.; Rivallain, M.; Sesana, M.M.; Olesen, B.W.; et al. TAIL, the new index for rating indoor environmental quality in offices and hotels undergoing deep energy renovation (EU ALDREN project). submitted. 